\title{
Deterrence and Geographical Externalities in Auto Theft
}

\author{
By Marco Gonzalez-Navarro
}

\section{Online Appendix}

\section{A. Data}

AMIS is a non-profit organization funded by insurance companies that compiles industry-wide theft and accident rates. These statistics are then used by members of the association to price insurance contracts. AMIS associated companies have a market share of over $80 \%$ of the automobile insurance market. Insurance companies not associated to AMIS are self-insured corporations that do not offer individual insurance to the public. In this sense, AMIS insures the population of individually-owned vehicles.

The database is generated continuously: when an insured vehicle is stolen, the owner calls his insurance company to file a report; as soon as the employee of the insurance company fills out the electronic report for the company's use, a copy of it is automatically sent to the compiling system at AMIS. Under this system, if a stolen vehicle is recovered, the report of the robbery is still preserved. As documented by Mansfield et al. (1974), failure to report insured missing vehicles is rare.

The econometric analysis uses variation in theft risk over time to identify the effect of Lojack. For that reason, the unit of observation should be car models whose theft risk can be followed throughout the analysis period. All theft cases of cars sold up to 1998 but stolen between 1999 and 2004 were not used as units of observation because of lack of data on the stock susceptible to being stolen. A second group of discarded observations consists of car models introduced into the market after Lojack was implemented. For these vehicles, it is impossible to analyze theft risk before Lojack was introduced. Similarly, some models were discontinued before the Lojack intervention. For these models, there is no posttreatment data available to analyze theft behavior, so they are left out. After these deletions, I have data on car models for which information on theft risk is available before and after Lojack was implemented. In total, there are 69 model-groups for which I have up to 21 observations in each of 32 Mexican states. The panel is unbalanced with triangular matrix form: For each model and state, I have up to 6 annual theft observations for the 1999 vintage, 5 annual theft observations for the 2000 vintage, and so on, with only one theft observation for the 2004 vintage. Throughout the paper, the term model is used to refer to the groupings of vehicles in Table 1. Table 2 provides the Lojack models that participated in the Lojack 
program as well as the introduction dates in each participating state. Figure 1 shows a histogram of thefts which motivates the use of a count data model.

\section{B. Measurement error}

This section reviews the implications for the analysis of using insured vehicle theft data together with total vintage size, instead of just the insured vehicles in the vintage. The intuition of the problem this presents is relatively simple: the estimates will be biased if Lojack generated changes in the likelihood of a Lojack-equipped vehicle being insured. If buying a car with Lojack made owners less likely to buy insurance, then this would mechanically reduce the number of cars exposed to theft that are captured in the data. The problem can be seen in terms of the estimated model. The data available, in which vintage size instead of the insured vehicles in the vintage is used as the exposure variable, can be understood as a situation in which the true exposure variable is overblown by a factor larger than one. Assume that $\pi_{s m}$ is the probability that a vehicle in state $s$ model $m$ is insured. Then the true stock of cars is $S_{s m v}^{\text {True }}=\pi_{s m} \cdot S_{s m v}^{O b s}$, where $S^{O b s}$ refers to the stock of vehicles observable to the econometrician, while $S^{\text {True }}$ refers to the actual stock of insured cars on the road. Then, if the true model is

$$
E\left[\text { Thefts } s_{s m v t} \mid \mathbf{x}_{s m v t}\right]=\left(S_{s m v}^{\text {true }}\right) \cdot \exp \left(\gamma_{s m}+f_{s}(t)+\delta_{\text {age }}+\beta_{1} L J_{s m v}\right)
$$

Substituting $S_{s m t}^{T r u e}=\pi_{s m} \cdot S_{s m v}^{O b s}$ in the equation above yields

$$
E\left[\text { Thefts } s_{s m v t} \mid \mathbf{x}_{s m v t}\right]=\left(S_{s m v}^{O b s}\right) \cdot \exp \left(\ln \left(\pi_{s m}\right)+\gamma_{s m}+f_{s}(t)+\delta_{a g e}+\beta_{1} L J_{s m v}\right)
$$

$\ln \left(\pi_{s m}\right)+\gamma_{s m}$ is then absorbed by the model and state-specific fixed effect and the error in the exposure variable does not bias the results. The statemodel fixed effect also addresses another type of error in the exposure variable: migration rates of vehicles that are not netted out between states, as long as they are constant throughout the panel years. In conclusion, the specification used is robust to multiplicative error in the exposure variable. However, a problem arises if there is temporal variation in $\pi_{s m}$ which is correlated with the introduction of the Lojack program. Under such scenario, the Lojack coefficient of interest is not identified. For this reason, I present evidence in the paper that: 1) Lojackequipped vehicles were just as likely to be insured as non-Lojack-equipped vehicles in the years after Lojack was introduced; and 2) insurance likelihood of Lojack models evolved in an identical manner to non-Lojack models once Lojack was introduced. This provides evidence that Lojack introduction was uncorrelated with insurance coverage probability $\left(\pi_{s m}\right)$, as required by the econometric model.

Both regressions lead me to conclude that Lojack did not induce a reduction in the probability of insuring vehicles for customers who bought Lojack-equipped cars. There may have been various reasons for this. People who bought the car with credit had no option of opting out of insuring their vehicle even if they wanted to. Another reason is that people value the services of insurance companies aside from theft coverage: insuring vehicle damage in case of accidents, medical expense 
insurance for vehicle occupants, and civil responsibility.

\section{Specification robustness checks}

I report the results of three robustness checks in Table 3. The first column is the main specification from Table 2 for comparison. Column 2 addresses the fact that the baseline estimations assume independence of error terms across states. This may not be a reasonable assumption if theft risk is spatially correlated across state lines. This is especially important because three of the Lojack states are contiguous. For the externality regressions, it is not difficult to imagine that Lojack states around a particular Lojack state may share common theft risk shocks. To address this concern, I place all contiguous Lojack states into a single cluster and all non-Lojack states surrounding a particular Lojack state into a single cluster. The panel shows that the results are robust to this redefinition of clusters.

Column 3 relaxes the assumption that the theft-risk function is a one-to-one relationship between the stock of vehicles and the number of thefts (by constraining the coefficient on the stock of vehicles to be equal to one in the regression). For example, consider the possibility that the demand for stolen vehicles is simply a target number of stolen cars, independent of the stock available (See Camerer, Babcock, Loewenstein, and Thaler (1997) for income targeting in the workplace). If this were the case, and Lojack generated an increase in sales of Lojack-equipped models, then my assumed specification would show a fall in theft risk, even though Lojack only generated an increase in sales. Any feature in a car that increased sales - like lower prices or more add-ons - would have the same effect as Lojack. Column 3 does not restrict the vintage size variable to have a coefficient equal to one. If the targeting hypothesis is true, then the vintage size coefficient should be smaller than one and the coefficient on Lojack should be sharply reduced (in absolute value). The results are virtually unchanged from the main specification. In conclusion, the targeting hypothesis does not seem be supported in the data.

Finally, column 4 explores whether Lojack state non Lojack model externalities were present in vehicles similar to Lojack models. This is done by defining LJmodel_category $=1$ if a non Lojack model is of the same category as a Lojack model (SUV, sedan, luxury sedan, minivan and compact car) or not (sports car, subcompact and pick-up truck). The coefficient on the interaction tells us if the Lojack externality was different among Lojack model category vehicles from those categories in which a Lojack model was not represented. The regression result is reported in column 4 of Table 3 . The interaction coefficient is negative, suggesting that vehicles similar to Lojack ones had a reduced theft risk after Lojack introduction compared to those dissimilar from Lojack ones. In conclusion, I find no evidence of cross model externalities in the data even within vehicles in the same category as Lojack models. 


\section{Figures and Tables}

Figure 1. Histogram of Thefts

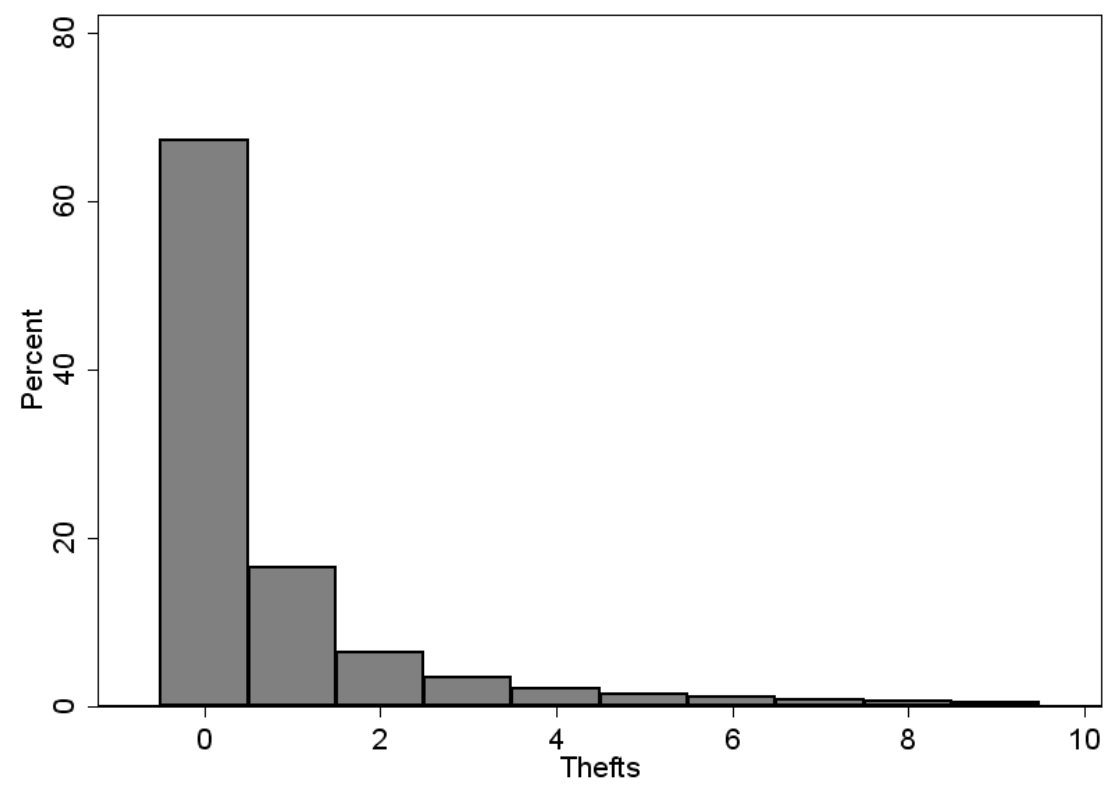

The unit of observation is the number of thefts in each model group, state, year made, and year stolen combination. Note: Graph truncated at 10 thefts for visibility purposes. The full distribution follows the same pattern. 


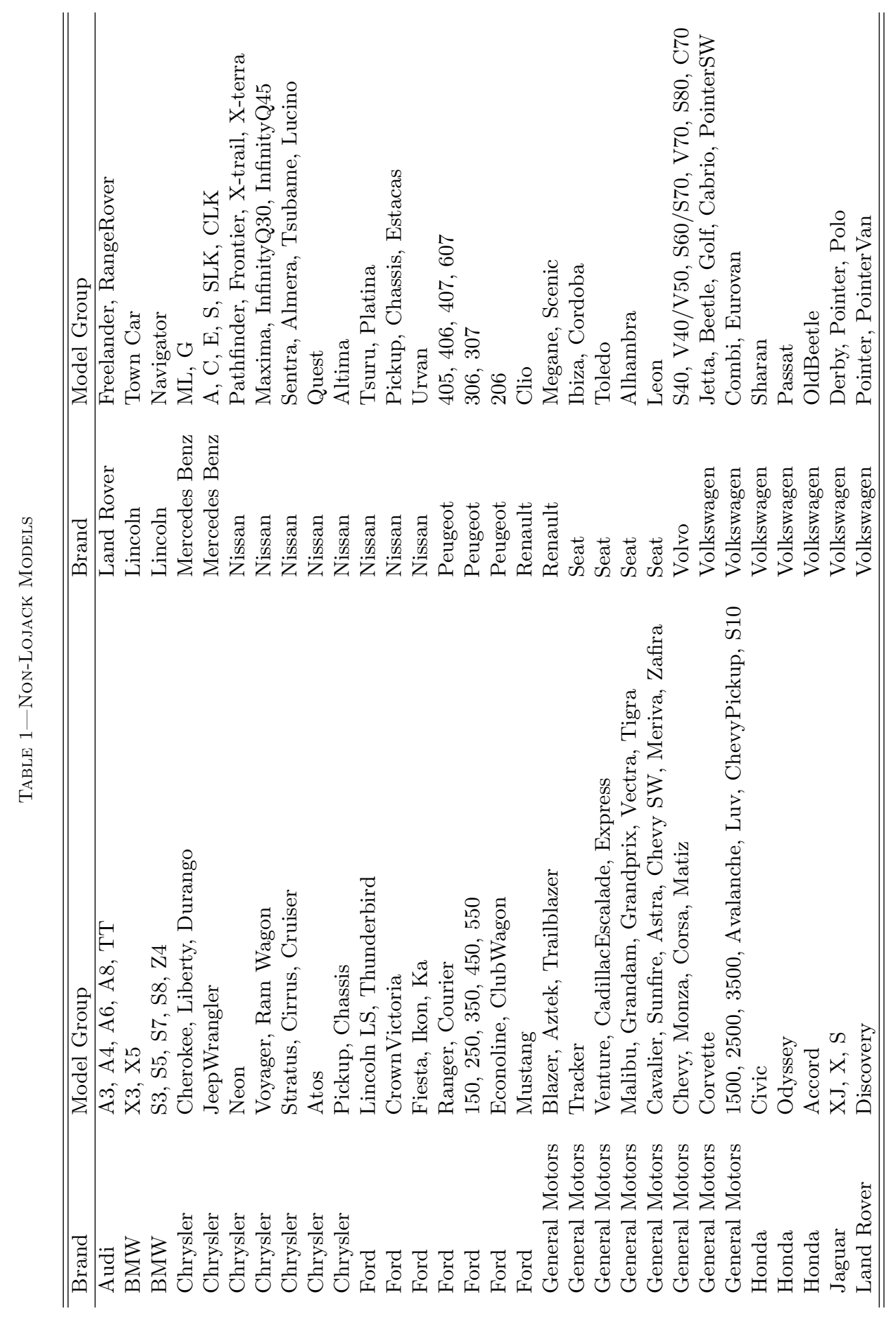


Table 2-States, Dates and Models where Lojack was Introduced

\begin{tabular}{lcccc}
\hline \hline LojackModels & Jalisco & Estado de Mexico & Distrito Federal & Morelos \\
\hline Ford Windstar & 2001 & 2002 & 2002 & 2002 \\
Ford Explorer & 2003 & 2003 & 2003 & 2003 \\
Ford Escape & 2003 & 2003 & 2003 & 2003 \\
Mercury Mystique & 2003 & 2003 & 2003 & 2003 \\
Ford Expedition & 2003 & 2003 & 2003 & 2003 \\
Ford Focus & 2003 & 2003 & 2003 & 2003 \\
Ford Excursion & 2003 & 2003 & 2003 & 2003 \\
Ford Grand Marquis & 2003 & 2003 & 2003 & 2003 \\
Mercury Sable & 2003 & 2003 & 2003 & 2003 \\
\hline \hline
\end{tabular}

TAble 3 - Specification Robustness Checks

\begin{tabular}{|c|c|c|c|c|}
\hline $\begin{array}{l}\text { Specification: Negative binomial } \\
\text { Dep. var.: Vehicle thefts }\end{array}$ & (1) & $(2)$ & (3) & (4) \\
\hline $\mathrm{LJ}=1$ & $\begin{array}{c}-0.66^{* * *} \\
(0.018)\end{array}$ & $\begin{array}{c}-0.66^{* * *} \\
(0.004)\end{array}$ & $\begin{array}{c}-0.92^{* * *} \\
(0.078)\end{array}$ & $\begin{array}{c}-0.66^{* * *} \\
(0.019)\end{array}$ \\
\hline NLJM LJS After $=1$ & $\begin{array}{c}-0.08 \\
(0.066)\end{array}$ & $\begin{array}{c}-0.08^{* * *} \\
(0.027)\end{array}$ & $\begin{array}{l}-0.05 \\
(0.101)\end{array}$ & $\begin{array}{l}-0.008 \\
(0.037)\end{array}$ \\
\hline LJM NLJS After $=1$ & $\begin{array}{c}0.42^{* * *} \\
(0.075)\end{array}$ & $\begin{array}{c}0.42^{* * *} \\
(0.077)\end{array}$ & $\begin{array}{c}0.35^{* * *} \\
(0.079)\end{array}$ & $\begin{array}{l}0.42^{* * *} \\
(0.075)\end{array}$ \\
\hline NLJM NLJS After $=1$ & $\begin{array}{c}0.05 \\
(0.056)\end{array}$ & $\begin{array}{c}0.05 \\
(0.065)\end{array}$ & $\begin{array}{c}0.074 \\
(0.056)\end{array}$ & $\begin{array}{c}0.05 \\
(0.056)\end{array}$ \\
\hline NLJM LJS After*LJmodel_category & & & & $\begin{array}{c}-0.089^{* * *} \\
(0.027)\end{array}$ \\
\hline Observations & 16,764 & 16,764 & 16,764 & 16,764 \\
\hline Time controls & quadratic & quadratic & quadratic & quadratic \\
\hline State specific time controls & yes & yes & yes & yes \\
\hline Sample & full & full & full & full \\
\hline
\end{tabular}

Standard errors clustered at the state level in parentheses. Regressions control for: size of vintage by model and state, state $\times$ model fixed effects, and age dummies. LJM, NLJM stand for Lojack model and non Lojack model, respectively. LJS and NLJS stand for Lojack and non Lojack program states, respectively. LJmodel_category is one for categories in which a Lojack model is represented. $*$ significant at $10 \%$; $* *$ significant at $5 \%$; *** significant at $1 \%$. 


\section{REFERENCES}

Camerer, C., L. Babcock, G. Loewenstein, and R. Thaler (1997): "Labor Supply of New York City Cabdrivers: One Day At A Time," Quarterly Journal of Economics, 112(2), 407-441.

Mansfield, R., L. C. Gould, and J. Z. Namenwirth (1974): "A Socioeconomic Model for the Prediction of Societal Rates of Property Theft," Social Forces, 52, 462-472. 